\title{
Ionic Liquids in Catalytic Biomass Transformation
}

\author{
Zhu Yinghuai ${ }^{1, *}$, Algin Oh Biying ${ }^{1}, X$ iao Siwei ${ }^{1}$, \\ Narayan S Hosmane ${ }^{2}$ and John A. Maguire ${ }^{3}$ \\ ${ }^{1}$ Institute of Chemical and Engineering Sciences, Jurong Island, Singapore \\ ${ }^{2}$ Department of Chemistry and Chemical Biology, \\ Northern Illinois University, DeKalb, Illinois \\ ${ }^{3}$ Department of Chemistry, Southern Methodist University, Dallas, Texas \\ ${ }^{1}$ Singapore \\ 2,3USA
}

\section{Introduction}

\subsection{Alternatives to fossil fuels - biomass}

For the past 150 years, coal, natural gas and petroleum functioned as our main sources of energy and chemicals. They provide an estimated $86 \%$ of energy and $96 \%$ of organic chemicals [1]. However, these natural resources will be depleted in the near future as studies has predicted that the global energy demand will grow over $50 \%$ by 2030 as shown in Figure 1 [2]. In addition, problem concerning global warming brought about from the emission of fossil fuels remains a major concern. Hence, there is an urgent need for us to seek alternative renewable and greener energy sources; the answer lies in biomass which possesses huge amounts of stored chemical energy. The stored chemical energy in biomass has the potential to be tapped to meet the rising energy demand.

Biomass is one of the most valuable products from living things where simple molecules such as $\mathrm{H}_{2} \mathrm{O}, \mathrm{CO}_{2}, \mathrm{~N}_{2}$ are transformed into complex substances activated or catalyzed by biochemical processes (e.g. photosynthesis). Trees trap approximately $1 \%$ of solar energy and transform them into biomass. This energy is stored in the form of complex molecules such as lignin, carbohydrates, proteins, glycerides and others. Carbohydrates or saccharides (cellulose, hemicelluloses and starch) constitute $75 \%$ of the plant biomass, with $40 \%$ of the carbohydrate fraction of biomass being cellulose and $25 \%$ being hemicelluloses. Biomass energy is derived from five distinct energy sources: garbage, wood, waste, landfill gases, and alcohol fuels. Being the most abundant renewable resource as described in Figure 2, with approximately production of $1.0 \times 10^{11}$ tons annually, biomass was recognized as the best candidate to replace fossil fuels [3].

The transformation of biomass into value added chemicals gives little or no harmful side products which address the pressing issue for greener alternatives to fossil fuels. Other than being renewable and abundant, biomass is a cost effective feedstock.

Cellulose, the major component of the carbohydrate fraction of biomass is hard to deal with. It is insoluble in most conventional organic solvent and water, which hinders the ease of 


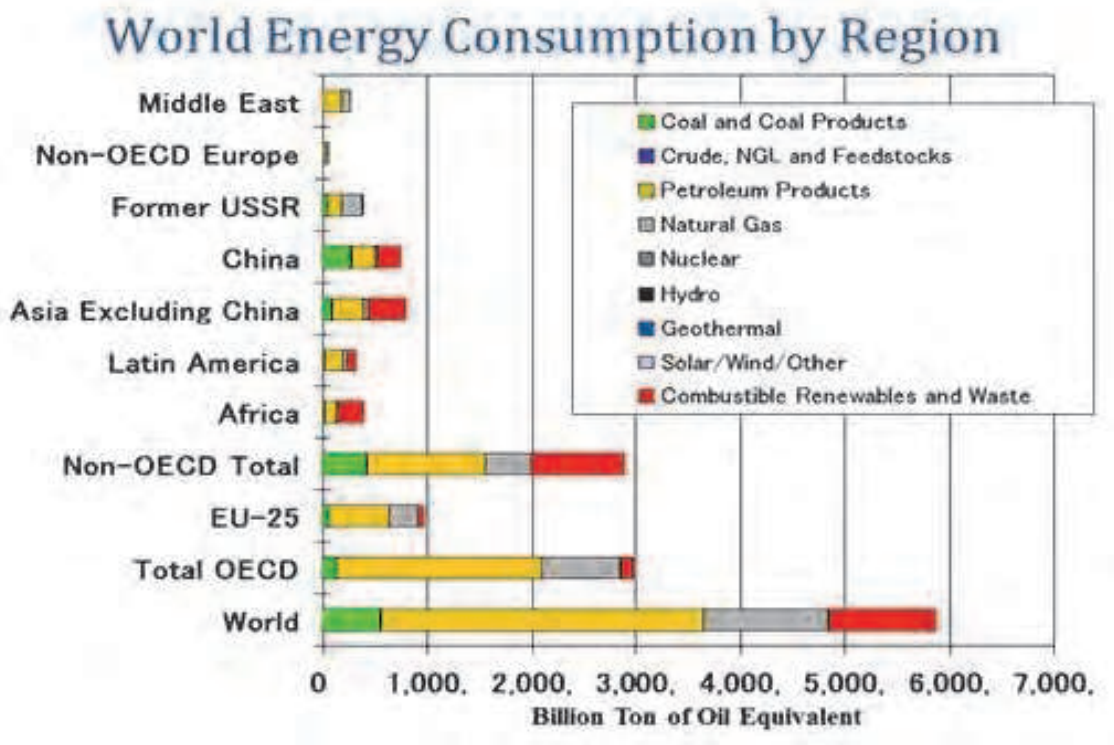

Fig. 1. World energy consumption by Region and will grow by $50 \%$ by 2030 (source: International Energy Agency (IEA) Non-Organization for Economic Co-operation and Development (OECD) Countries Energy Balance 2003).

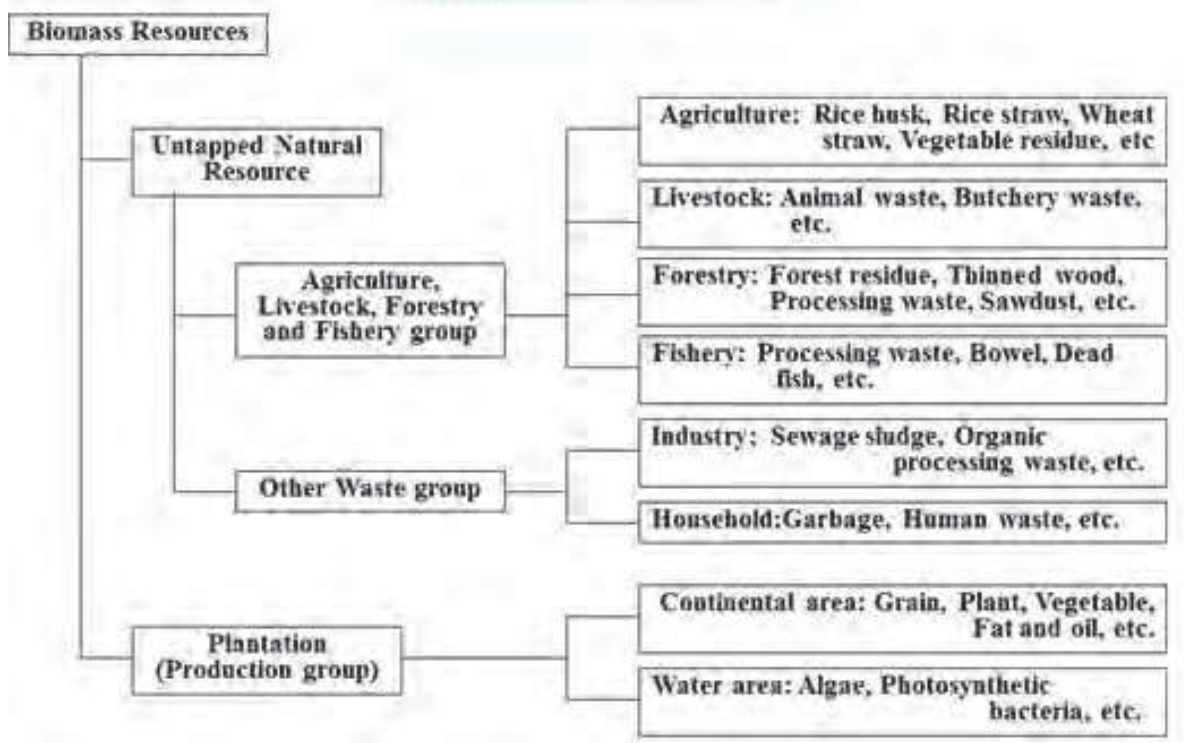

Fig. 2. Types of biomass resources. 
transforming it into monosaccharides such as glucose. New solvents have to be sought which are able to dissolve the cellulose so as to disrupt the crystallinity structure of the cellulose and make it more susceptible to transformation into monosaccharides such as glucose.

Lignocellulosic cellulose refers to plant biomass which is made up primarily of cellulose, hemicellulose and lignin. Lignin acts as a strong adhesive holding the cellulose and hemicellulose together which makes lignocellulosic cellulose microbial and moisture resistant and imparts its rigid structure. Therefore, we need to devise a method to remove or reduce the lignin content in order to take advantage of the stored energy in lignocellulosic cellulose.

The problems of dissolving cellulose or reducing the lignin content have to be overcome. Ionic liquids (ILs) are a group of new organic salts that exist as liquids at relatively low temperatures can offer a solution to these problems. ILs can dissolve cellulose as well as remove or reduce the lignin content in lignocellulosic cellulose. ILs, based on polar organic solvents such as DMF, DMAc, DMI or DMSO and usually coupled with charged species such as $\mathrm{LiCl}$, are frequently used for dissolving cellulose, while methyl methylsulfate imidazolium-based ILs show excellent results when dissolving softwood Kraft lignins.

\section{2 lonic liquids: Types and classfication}

ILs is a group of new organic salts that exist in the liquid state at relatively low temperatures. An ideal IL for cellulose transformation should possess the following properties: (1) high dissolution capacity for cellulose; (2) low melting point; (3) good thermal stability; (4) non-volatile; (5) non-toxic; (6) chemically stable; (7) no cellulose decomposition; (8) easy cellulose regeneration and (9) low cost and simple process [4]. Imidazolium is one of the most commonly used cations of ILs, while anions include quite a number such as chloride, hexafluorophosphate, tetrafluroborate and others, as shown in Figure 3, and 4. To improve the solubility of cellulose and lignocellulose in ILs, it is important to optimize the suitable anions and cations in ILs, sometimes necessitating structural modifications.

\subsection{Ionic liquids: Synthetic methods}

Although a variety of methods have been reported for synthesizing ILs [5], the most commonly used procedures are summarized in Figure 5 and 6. (1) Path A: Metathetic exchange of anion. This is the most commonly used method to synthesize ILs. The downside of this method is that it produces harmful halide by-products ( $\mathrm{MX}$ such as $\mathrm{AgCl}$, etc.) which are difficult to remove by filtration, particularly for hydrophilic ILs. (2) Path B: neutralization of base with brØnsted acids and Path C: direct alkylation of alkylimidazole. Path $B$ and $C$ are more environmentally benign reactions as they do not produce halide byproducts. However for path B, it can be hard to produce ILs with high purity; minute amounts of alkylimidazole or acid impurities could be present in the resulting ILs. For path $\mathrm{C}$, it is restricted to the reactivity and availability of the alkylating agents. It is used to prepare sulfate, phosphate or sulfonate based ILs. (3) Path D is similar to Path A in that it involves a metathetic exchange of anions. This method uses dimethylcarbonate (DMC) as a clean methylating agent to substitute alkyl halides. It can prevent the formation of halide and other by-product that makes the ILs efficient [5]. The downside of this method is that it is restricted by the availability of the acid (HX) or $\mathrm{NH}_{4}{ }^{+}$salts. (4) Non-conventional routes to synthesize ILs. Synthesis of ILs using non-conventional method such as microwaves and 
Cations:

a) Imidazolium<smiles></smiles>

[mim]<smiles></smiles>

[emim]<smiles>CCCCn1ccn(C)c1=O</smiles>

[bmim]<smiles></smiles>

[emmim]<smiles></smiles>

[hmim]<smiles>CCCCCCCCn1ccn(C)c1=O</smiles>

[omim]<smiles></smiles>

[bmmim]<smiles></smiles>

[ASBI]<smiles></smiles>

[ASCBI]<smiles></smiles>

Pyridinium

Pyrrolidinium

Ammonium

Guanidinium<smiles></smiles><smiles>CN1CCCC1=O</smiles><smiles>CCN</smiles><smiles>CN(C)C(=[NH2+])N(C)C</smiles>

Py

[nmp]

[tmg]

b) choline based

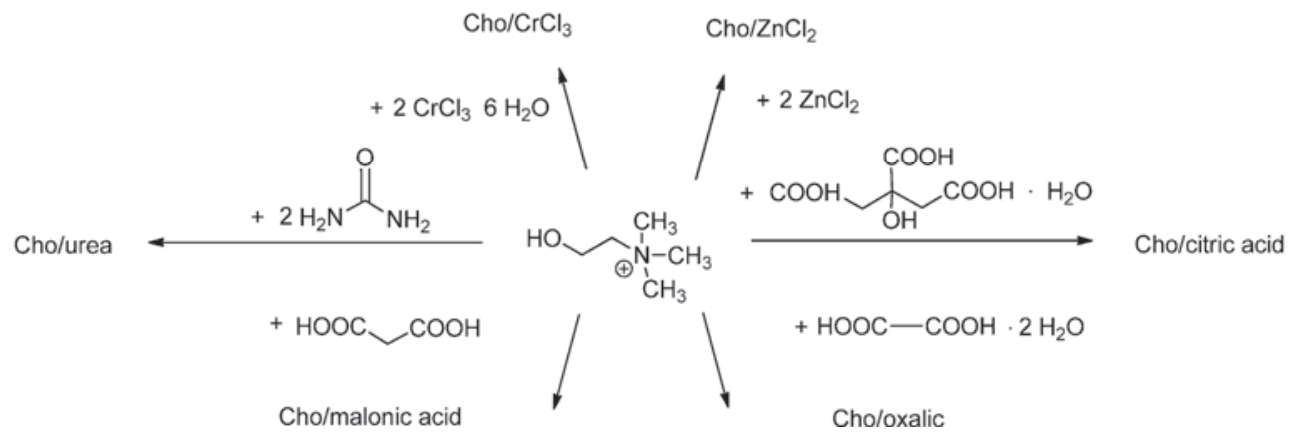

Fig. 3. (a) Most common cations of ILs. (b) Choline cations of ILs obtained by mixing of choline chloride based IL with the molecular donors (presented along the arrows). 
ultrasounds are also possible. The disadvantage is that the ILs may decompose under sonochemical conditions [6]. There are also other reports of synthesizing ILs using nonconventional methods. An example is $[\mathrm{BMIM}]\left[\mathrm{BF}_{4}\right]$ that has been synthesized via a one-potsolvent-free route in a batch-mode reactor using microwave radiation (frequency of $5.8 \mathrm{GHz}$ ), giving a high yield of $87 \%$ [7]. Successful synthesis of [BMIM][OH] in solution using an electro-dialysis set-up has also proven to be effective [8]. (5) Direct access to anionfunctionalized ILs. The route to the direct access of anion-functionalized ILs is the one-step ring-opening reaction of sulfones (Figure 6). This route generates zwitterions which possess high melting points and can react with acids or $\mathrm{LiNTf}_{2}$ to form new functionalized ILs [9]. This mixture, though very viscous, exists in liquid state at room temperature and is ionically conductive.

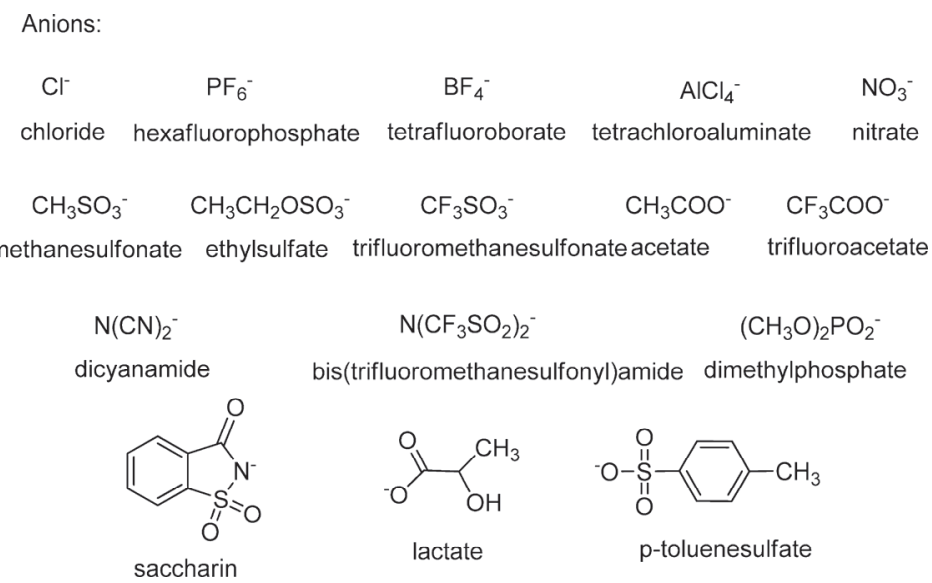

Fig. 4. Some anions of ILs [4].

Path A

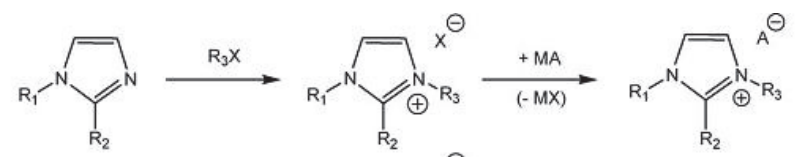

Path B

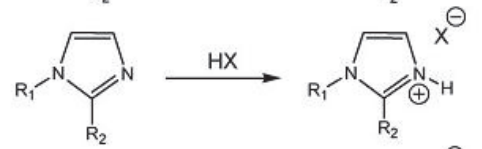

$\underline{\text { Path C }}$

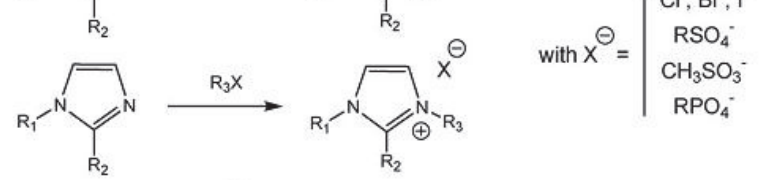

Path D

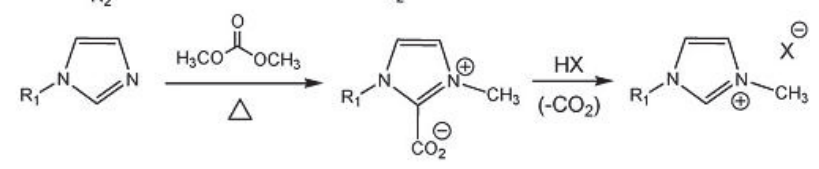

Fig. 5. General route for ILs synthesis. Path A: metathetic exchange of anion. Path B: neutralization of base with BrØnsted acids. Path C: direct alkylation of alkylimidazole. Path D: the carbonate method. 


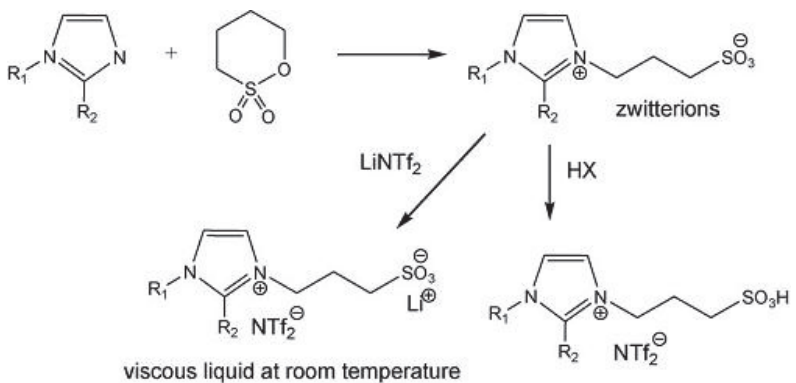

Fig. 6. Direct access to functionalized ILs.

\section{Transformation of polysaccharides to monosaccharides}

\subsection{Solubility behavior of biomass in ionic liquids}

Cellulose is made up of a linear chain with several $\beta-(1 \rightarrow 4)$ linked glucose repeating units (Figure 7). They are highly packed together with strong intra and inter hydrogen bonding and van der waals interactions between the cellulose fibrils. This accounts for its insolubility in water and conventional organic solvents except for concentrated phosphoric acid. Using concentrated phosphoric acid, however gives rise to environmental problems associated with the disposal of the solvent. Therefore, alternative solvents which are more benign have to be sought. Dissolving the cellulose can disrupt the highly crystalline structure in the cellulose to give amorphous cellulose which makes it more susceptible to transformation into monosaccharides such as glucose. Finding a suitable solvent to dissolve the cellulose is of utmost importance as it can affect its physical properties which include the degree of polymerization, its crystallinity and even the surface area of the substrate accessible in the case of further enzymatic hydrolysis. Some of the frequently used solvents in the dissolution of cellulose can be found in Table 1[10]. They are ionic liquids (ILs) based on polar organic solvents such as DMF, DMAc, DMI or DMSO usually coupled with charged species such as $\mathrm{LiCl}$, etc.

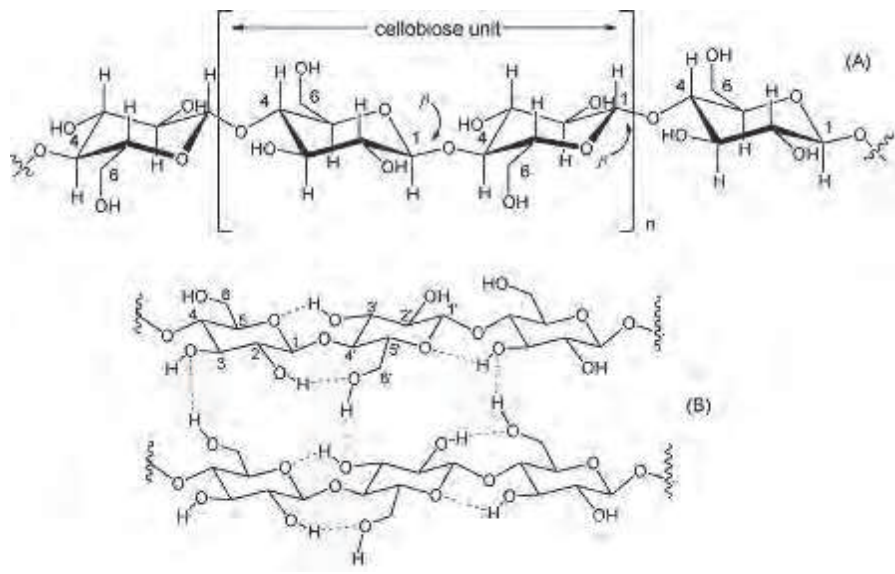

Fig. 7. The cellulose network (A: Cellulose chain and B: inter and intra H-bonds present in cellulose). 


\begin{tabular}{ll}
\hline Acronym & Main systems used to dissolve cellulose \\
\hline DMSO/TBAF & $\begin{array}{l}\text { Dimethyl sulfoxide/tetrabutylammonium } \\
\text { fluoride }\end{array}$ \\
$\mathrm{LiCl} / \mathrm{DMAc}$ & Lithium chloride/dimethylacetamide \\
$\mathrm{LiCl} / \mathrm{DMI}$ & Lithium chloride/dimethylimidazolidinone \\
$\mathrm{LiCl} / \mathrm{NMP}$ & Lithium chloride/N-methyl pyrrolidine \\
$\mathrm{N}_{2} \mathrm{O}_{4} / \mathrm{DMF}$ & Dinitrogen tetraoxide/dimethylformamide \\
$\mathrm{DMSO} / \mathrm{CH}_{2} \mathrm{O}$ & Dimethyl sulfoxide/paraformaldehyde \\
$\mathrm{NMMO}$ & N-methylmorpholine-N-oxide monohydrate \\
& Aqueous solutions metal complexes \\
\hline
\end{tabular}

Table 1. Main solvent systems used in manufacturing cellulose and cellulose derivatives.

Dissolution of cellulose is highly dependent on the nature of the native cellulose (its degree of polymerization (DP) and its crystallinity), the operating conditions (temperature, reaction duration, initial concentration of cellulose in the IL, activation with microwaves) and presence of impurities such as water. Water can affect the dissolution of cellulose significantly. Optimal dissolution can be achieved with extremely dried ILs.

Both the cations and anions of ILs contribute to the dissolution of cellulose. The mechanism of the dissolution is that the anion of the IL acts as H-bond acceptor that interacts with the hydroxyl group of cellulose in a stoichiometric manner to generate an electron donorelectron acceptor (EDA) complex [4]. The cation, on the other hand, with its electron-rich aromatic $\pi$ system acts as an electron acceptor center and prevents the cross linking of the cellulose. When the anion and the cation are in close proximity to each other, the formation of the EDA complexes between cellulose and ILs become feasible and the network of hydrogen bonds between the glycosidic monomers are disrupted, resulting in dissolution of the cellulose.

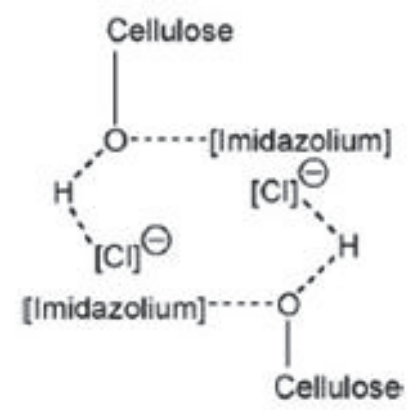

Fig. 8. Possible insertion of an imidazolium chloride in the cellulose matrix [4].

By adding a non-dissolution solvent such as water, ethanol or acetone, cellulose miscible in ILs can be precipitated from solution and then separated from the mixture of IL and nondissolution solvent either by filtration or centrifugation. Due to non-volatile nature of IL, it can be recovered by distillation of the mixture, thus eliminating the non-dissolution solvent. The precipitated cellulose can appear in different forms such as monoliths, fibers and films and can have the same degree of polymerization and polydispersity as native cellulose but it 
depends largely on the operating conditions of the precipitation. Varying the condition of the precipitation can alter the degree of crystallinity of the precipitated cellulose. For example, cellulose precipitated after being dissolved in [AMIM][Cl] and [BMIM][Cl] had lower degree of crystallinity than native cellulose [11]. Results show that the precipitated cellulose is mostly amphorous with greater accessibility of the polysaccharides chains in the cellulose and exhibits enhanced enzymatic hydrolysis kinetics (Figure 9) [12-14].

\begin{tabular}{|c|c|c|c|c|}
\hline \multirow{2}{*}{ Crystalline cellulose } & $\begin{array}{c}\text { Primary hydrolysis } \\
\text { Solid phase }\end{array}$ & \multirow{2}{*}{$\begin{array}{l}\text { Soluble } \\
\text { oligomers }\end{array}$} & $\begin{array}{l}\text { Secondary hydrolysis } \\
\text { Liquid phase }\end{array}$ & \multirow[t]{2}{*}{ Glucose } \\
\hline & Slow and rate limiting & & Fast & \\
\hline \multicolumn{5}{|c|}{$\begin{array}{c}\text { Physical/chemical } \\
\text { treatment }\end{array}$} \\
\hline \multirow{2}{*}{ Amorphous cellulose } & $\begin{array}{l}\text { Primary hydrolysis } \\
\text { Solid phase }\end{array}$ & \multirow{2}{*}{$\begin{array}{l}\text { Soluble } \\
\text { oligomers }\end{array}$} & $\begin{array}{l}\text { Secondary hydrolysis } \\
\text { Liquid phase }\end{array}$ & \\
\hline & Fast & & Fast & Glucose \\
\hline
\end{tabular}

Fig. 9. Enzymatic hydrolysis of cellulose.

\subsection{Lignocelluloses and challenges in their transformation}

Lignocellulosic cellulose [4] refers to plants biomass which is made up primarily of cellulose, hemicellulose and lignin. Various challenges are faced when trying to convert lignocellulosic cellulose into fuels and other value added chemicals due to the existence of cellulose and lignin. Hemicellulose can be easily degraded but the highly crystalline structure cellulose makes it resistant to chemical and biological degradation. Lignin also poses a problem as it acts as an "adhesive" that holds hemicellulose and cellulose together, accounting for the microbial and moisture resistance and its rigid structure. Hence, it is necessary to devise methods to reduce or remove the lignin content and to disrupt the crystalline structure.

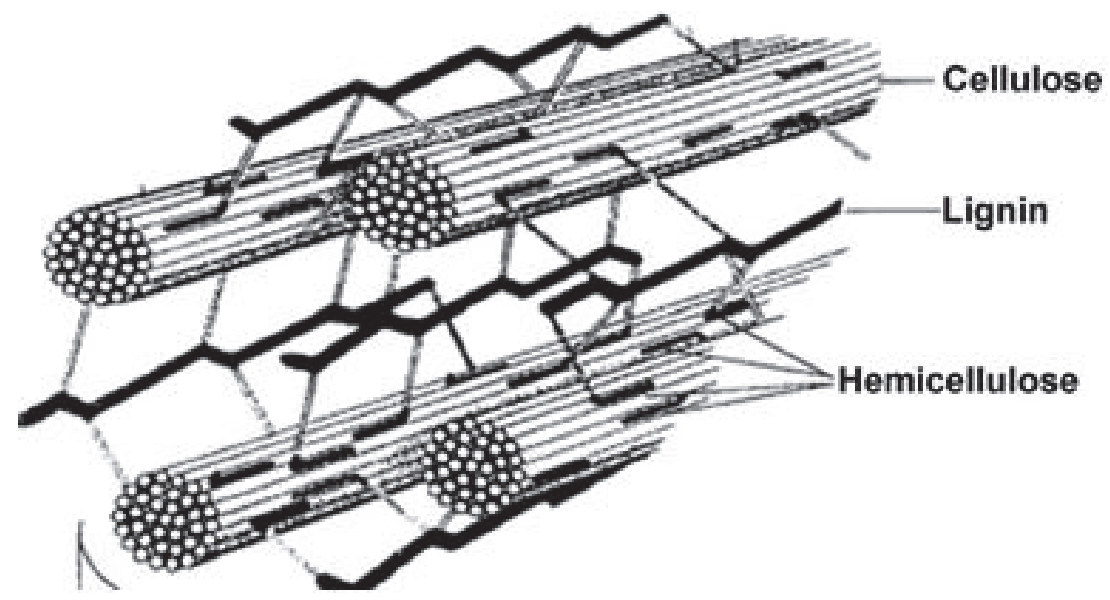

Fig. 10. Lignocelluloses network. 
Various methods have been devised to reduce or remove the lignin content in lignocellulosic cellulose which includes physical (limited pyrolysis and mechanical disruption/comminution [15]), physiochemical (steam explosion, ammonia fiber explosion $[16,17])$, chemical (acid hydrolysis, alkaline hydrolysis, high temperature organic solvent pretreatment, oxidative delignification [18-20]), and biological (lignin degradation by whiteand soft-rot fungi [21]) methods. The same problem arises from using these methods to extract lignin. After the removal of sufficient amount of lignin, the lignin experiences degradation and often results in the loss of fermentable sugar content in the polysaccharides.

The removal or reduction of lignin and disrupting the crystalline structure of lignocellulosic cellulose to make it more accessible to chemical and biological transformation remains a great challenge. Various works have been done to address these issues and the usage of ionic liquids (ILs) became a solution to this challenge. For example, research has shown that methylsulfate imidazolium-based ILs produce excellent results when dissolving softwood Kraft lignin [22]. Other research demonstrated that extraction of lignin from bagasse using the IL ethyl-methylimidazolium alkylbenzenesulfonate [EMIM][ABS] was successful giving a yield of $>93 \%$ at atmospheric pressure. Although ILs proved to be effective in the dissolution of lignin, several problems such as the simplification of IL and the high operating temperature still exist [23].

Research has shown that when $40 \%$ of the lignin was extracted with a well chosen IL ([EMIM][Ac]), the cellulose crystallinity index dropped below 45 and the resulting hydrolysis of the wood flour cellulose was measured to be above $90 \%$. This confirmed the close correlation between lignin extraction and residual cellulose crystallinity [11]. Another research group came to the conclusion that delignification alone was sufficient for effective hydrolysis over longer periods whereas for shorter hydrolysis times the combination of delignification and de-crystallization showed great benefits [24].

Pre-treatment of lignocelluloses leads to eventual fractionation of lignocelluloses which allow the disruption of the crystalline structure of the lignocellulosic cellulose to make it more accessible to chemical and biological transformation. An improved enzyme use in the cellulose hydrolysis step, with the possibility of enzyme recovery generates higher sugar yield with lower sugar degradation and less inhibitor formation. Generally, choosing a suitable pre-treatment will be the result of a compromise between hemicellulose and cellulose degradation and the ease of enzymatic hydrolysis of cellulosic substrate.

The two conditions needed for wood solubilization are wood particle size and the water content in the wood. Research has shown that water has a negative effect on the solubility of wood in ILs. The wood particle size can restrict the diffusion of IL into its interior causing poor dissolution of the wood particles. The relationship between lignin solubilization and wood dissolution is not clear; some ILs such as [MMIM][MeSO $\mathrm{M}_{4}$ can solubilize lignin without affecting the wood [11]. The best solvent for lignocellulosic materials was found to be $[\mathrm{BMIM}][\mathrm{Cl}]$ and for hardwood and softwood, it was [AMIM][Cl] $[11,25]$. The assistance of microwaves can greatly improve the dissolution of wood. A $5 \mathrm{wt} \%$ of six biomass types were rapidly and entirely dissolved in $[\mathrm{BMIM}][\mathrm{Cl}]$ with the aid of microwave irradiation [26].

\subsection{Transformation of polysaccharides to monosaccharides}

Monosaccharides are the most basic units of biologically important carbohydrates and exist as the simplest forms of sugar. Polysaccharides are polymeric carbohydrate structures, 
formed of repeating units of monosaccharides or disaccharides joined together by glycosidic bonds.

\subsubsection{Acid-catalyzed cellulose hydrolysis}

The transformation of polysaccharides to monosaccharides can be achieved via acidcatalyzed cellulose hydrolysis. Although acid-catalyzed cellulose hydrolysis existed for many years, no alternate cost effective solutions can be offered for the transformation on a large-scale. Another downside is that, due to the involvement of acid, there is a need for non-corrosive materials and the acid must be removed or neutralized after the treatment, otherwise, the disposal of the acid will present be difficulties. The harsh conditions such as the high temperature and pressure for the hydrolysis can form degradation of products which lower the monosaccharides yield and prevent further fermentation.

Hence, acid-catalyzed cellulose hydrolysis remained a challenge prior to the introduction of ILs. When the acid-catalyzed cellulose hydrolysis was carried after cellulose was dissolved in ILs, the hydrolysis occurred at a lower temperature and with lower catalyst loading. The strength of the acid used also makes a major contribution to the successful hydrolysis. The optimized condition was determined to be a strong acid, water content between $5 \%$ and $10 \%$ $(\mathrm{w} / \mathrm{w})$, carbohydrate content less than $10 \%(\mathrm{w} / \mathrm{w})$ and temperature range 80 and $150^{\circ} \mathrm{C}[4]$.
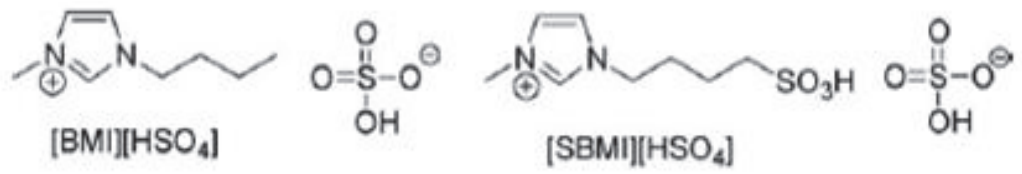

Fig. 11. ILs used for catalytic hydrolysis of lignocelluloses [4].

\subsubsection{Enzyme-catalyzed cellulose hydrolysis}

Enzyme-catalyzed cellulose hydrolysis is not very popular due to the high costs incurred and the lack of a feasible method for recovering the enzyme. Enzyme hydrolysis also suffers from low reaction rates that makes it undesirable. Dissolving cellulose in ILs generally involved interactions of the anions that create strong hydrogen bonding with the cellulose; this poses a serious problem of denaturing the enzyme. New types of ILs have been devised to counter the problem of inactivating enzymes [4].

\subsubsection{Transition metal nanoparticle-catalyzed cellulose hydrolysis}

Transition metal nanoparticle catalytic systems displayed excellent catalytic activities. Due to their small particle size and large surface area, they offer higher selectivity in comparison with conventional heterogeneous catalysts. The ILs used to dissolve the cellulose acts as a stabilizer for transition metal nanoparticles to maintain their small size, large surface area and to prevent nanoparticles from leaching. Boronic acids were predicted to disrupt the crystallinity of cellulose by binding reversibly with the numerous hydroxyl groups of cellulose, thereby improving the solubility and catalytic activity of cellulose, leading to the formation of 1 (Figure 12) [27]. Compound 1 serves as an excellent catalyst when coupled with the ILs-stabilized ruthenium nanoparticles for cellulose conversion. The catalyst has the advantage of being recycled which makes it desirable for cellulose hydrolysis. 


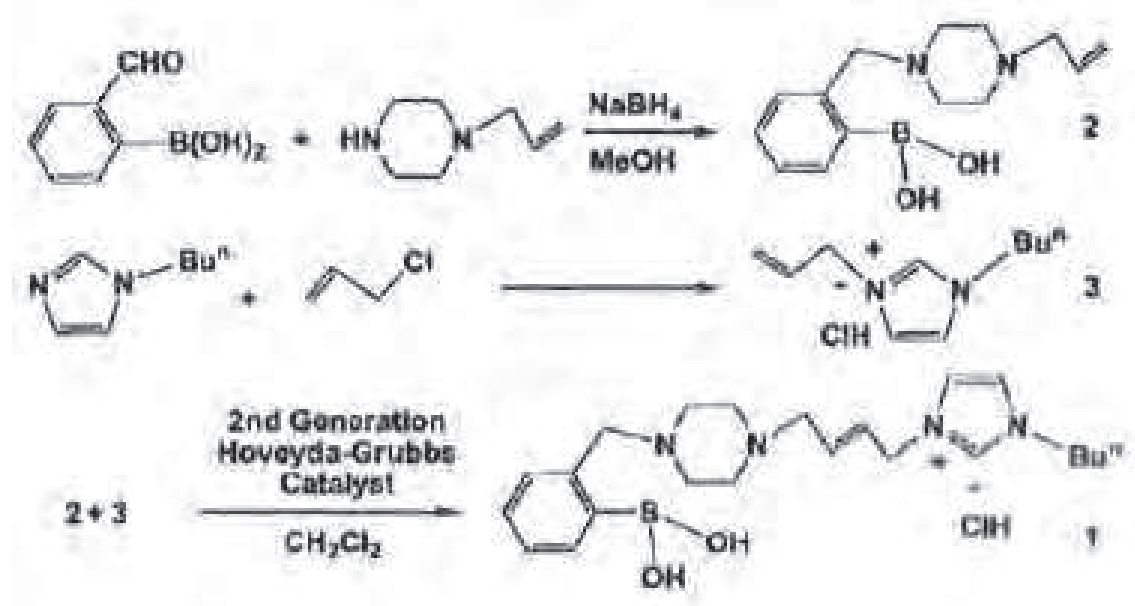

Fig. 12. Formation of boronic acid binding agent [27].

\subsection{Conclusions}

The use of ILs offers a good solution towards a more efficient transformation of polysaccharides to monosaccharide. But certain issues that arise with ILs must be addressed. ILs still remain expensive and the more work has to be done to reduce their costs as well as to improve on their recovery and reuse. After the pretreatment of lignocellulosic cellulose to remove lignin, methods of recovering the lignin should be explored to further tap its potential to be a combustible material and channeled for different usage.

\section{Transformation of saccharides to 5-hydroxymethylfurfural (5-HMF) and other value added chemicals}

When the ever declining fossil fuels meet with the ever increasing demands for energy, more and more people will be seeking renewable alternatives and product sustainability. Biomass has the potential to serve and excel as a sustainable source of energy and biomass resources are useful in many industrial applications. The basic chemical transformations include hydrolysis of cellulose to carbohydrates and the subsequent selective dehydration, hydrogenation, oxidation and condensation to yield the various useful chemicals. There are reports on the catalytic conversion of carbohydrates to liquid alkanes $\left(C_{3}-C_{15}\right)$ and useful industrial chemicals such as 5-hydroxymethylfurfural (5-HMF), levulinic acid and furfural. Among the various possible types of biomass-derived chemicals, 5-hydroxymethylfurfural (5-HMF) seems to be the most promising building block that could substitute for the petrochemicals that are used in plastics, pharmaceuticals, fine chemicals and biofuels.

This part will discuss the use of ionic liquids and their role in the key chemical transformations of saccharides into value added chemicals such as 5-HMF. We also hope to provide some insights into the key mechanism of the transformation reactions; compile, discuss, elaborate, compare and contrast the different types of catalyst system, reaction conditions, reactors, solvents and novel techniques reported. 


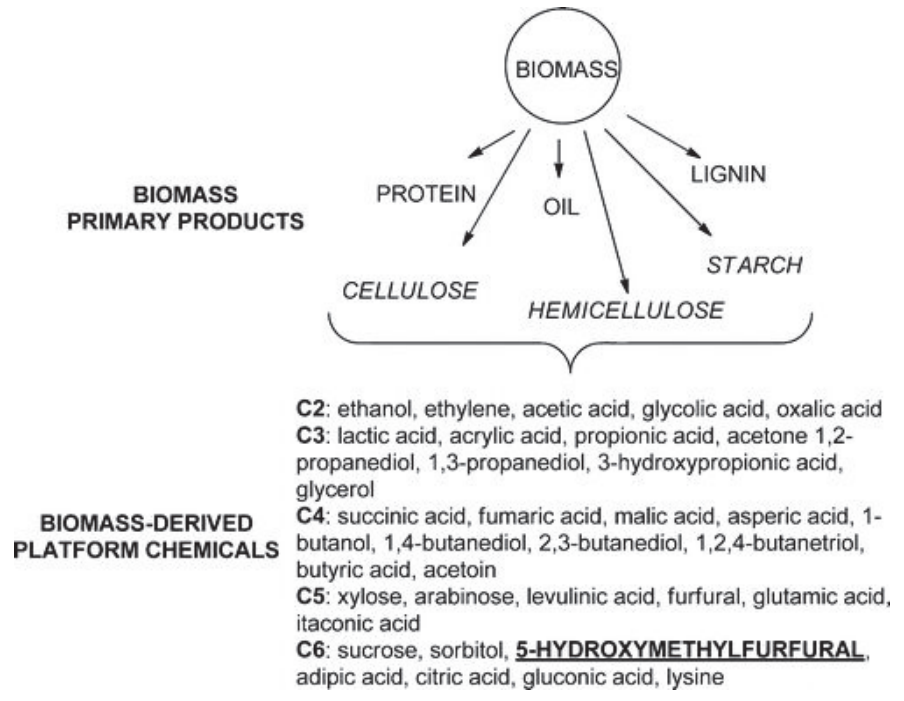

Fig. 13. Proposed biomass-derived platform chemicals.

\subsection{5-hydroxymethylfurfural (5-HMF) and its applications}

5-hydroxymethylfurfural (5-HMF) (Figure 14) is a furan based raw material that has been named one of the top building block materials obtained from biomass. It comprises an aromatic alcohol, aldehyde and furan ring system. Its expected usage is in the production of resins, fine chemicals, pharmaceuticals, polymers (polyester), solvents and liquid transportation fuels (2,4-dimethylfuran, a biofuel has $40 \%$ higher energy density than ethanol does [28]).

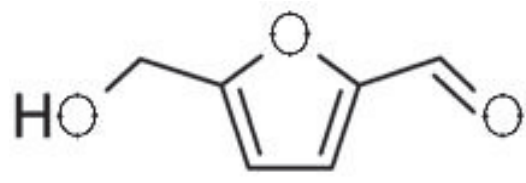

Fig. 14. Structure of 5-hydroxymethylfurfural (5-HMF)

Since it was first reported in the 19th century, 5-HMF has attracted much interest. Thereafter, much research and studies have been carried out to elucidate the structure, reaction mechanism, physical properties, chemical behaviours of 5-HMF. Antal et al. showed that 5HMF was formed from hexoses via an acid catalyzed dehydration with the removal of three water molecules (Figure 15) [19].

About thirty years ago, van Dam and Cottier, et al. showed that an aqueous and nonaqueous process could produce $37 \%$ yield of 5-HMF. In the aqueous part of the system, 5HMF takes up two molecules of water to form levulinic and formic acid while in the nonaqueous part, the hydrolysis of 5-HMF is suppressed. Nonetheless, cross-polymerization occurred under all circumstances leading to the formation of colored soluble polymers and insoluble brown precipitates. Thus, there is a need to come up with a suitable catalyst or a system for the selective formation of 5-HMF while not promoting the consecutive reactions 
leading to the formation of side products. Alternatively, continuous removal of 5-HMF from the reaction mixture would be an ideal process.

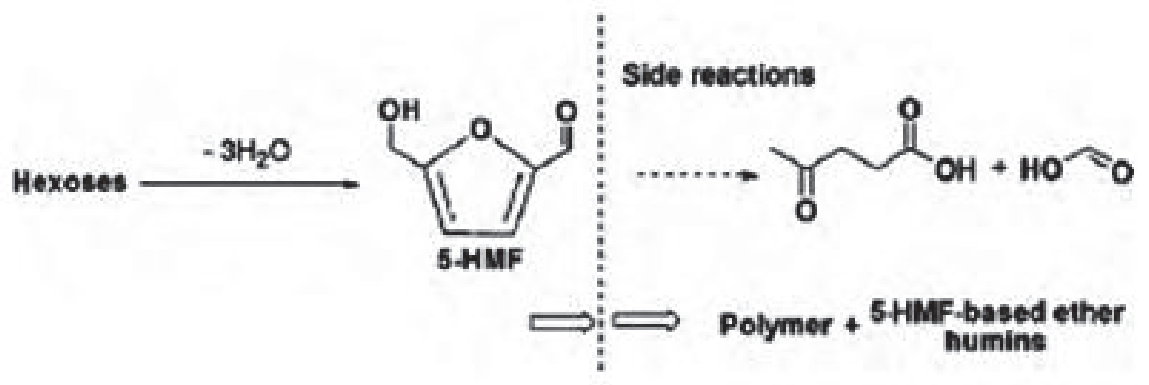

Fig. 15. Production of 5-HMF and the corresponding side reactions.

\subsection{Dehydration of monosaccharides to 5-hydroxymethylfurfural (5-HMF) in ILs}

1n 1983, the first report on the conversion of fructose to 5-HMF in the presence of pyridinium chloride with $70 \%$ yield under mild reaction conditions $\left(30 \mathrm{~min}, 120{ }^{\circ} \mathrm{C}\right.$ ) was published [30]. This sparked an interest in investigating the dehydration of fructose over molten salts. Twenty years later, in 2003, Lansalot-matras et al. revisited the field and investigated the acid-catalyzed dehydration of fructose in commercially available ionic liquids, ([BMIM] $\left.\left[\mathrm{BF}_{4}\right]\right)$ and $\left([\mathrm{BMIM}]\left[\mathrm{PF}_{6}\right]\right)$ with $\mathrm{DMSO}$ as co-solvent in the presence of Amberlyst-15 [31]. They demonstrated the advantages of using ILs as solvents and reported a yield of $80 \%$ for $5-\mathrm{HMF}$ in $24 \mathrm{~h}$ and at a relatively low temperature of $80^{\circ} \mathrm{C}$ compared to that employed in the previous method. However, conventional methods require much higher temperatures of 100 to $300^{\circ} \mathrm{C}$ [31]. In an effort to further improve the dehydration reaction, the following reaction parameters were studied extensively with promising results:

\subsubsection{Temperature and solvents}

Qi et al. employed ionic liquid [BMIM][Cl] with different co-solvents such as DMSO, acetone, methanol, ethanol, ethyl acetate and supercritical carbon dioxide [32]. Fructose was first dissolved in ILs at $80^{\circ} \mathrm{C}$ and added Amberlyst-15, a strong acidic ion-exchange resin catalyst, and co-solvent was added to give a gel-like mixture after cooling. It was demonstrated that the reaction could proceed at an ambient temperature of $25^{\circ} \mathrm{C}$ with yields of $78 \%-82 \%$ for 5-HMF [32].

\subsubsection{Biphasic system}

Zhang and co workers have demonstrated the first efficient room temperature catalytic system by using [BMIM][Cl] with tungsten chloride and a biphasic system composed of ILs and a modifier, tetrahydrofuran (THF) (see Figure 16) [33].

\subsubsection{Metal halides as catalysts}

Glucose and fructose are isomeric hexoses. Fructose is the direct and most efficient starting material for the formation of 5-HMF using old and conventional dehydration methods. For industrial application, glucose is converted to fructose using enzymatic hydrolysis. 


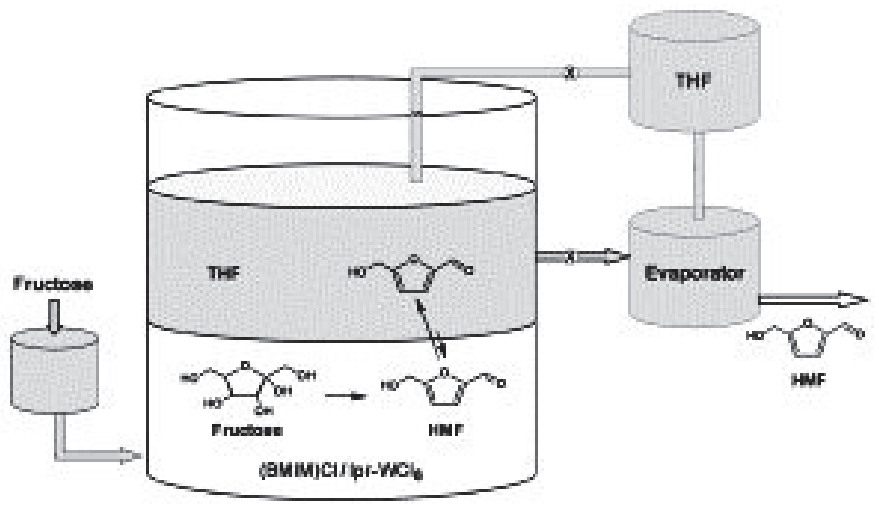

Fig. 16. Continuous batch process for the conversion of fructose to 5-HMF in a THF([BMIM][Cl]) biphasic system [33].

Therefore, a number of investigations were made to examine whether the direct conversion of glucose to 5-HMF was viable. Zhao et al. made a major breakthrough by showing that $\mathrm{CrCl}_{2}$ with IL [EMIM][Cl] are effective catalysts for the conversion of glucose to 5-HMF with a relatively good yield of $70 \%$ (Figure 17) [34]. This discovery, paved the way for the direct conversion of cellulose to 5-HMF in ILs under mild conditions (55\% yield) [1], while microwave-assisted route gave $61 \%$ yield of the product $[3,35]$.

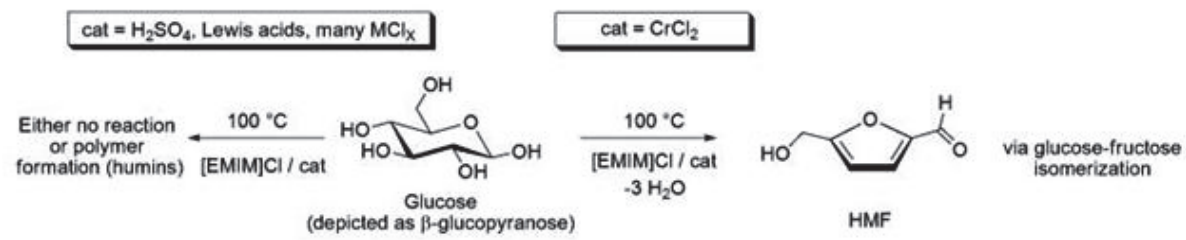

Fig. 17. Glucose conversion to $5-\mathrm{HMF}$ at $100^{\circ} \mathrm{C}$ [34].

\subsection{Mechanism}

It has been proposed by Zhao et al. [34] that the reaction follows two possible pathways: (1) series of cyclic furan intermediates (A); (2) Open-chain pathway included formation of an enediol as an intermediate in the isomerization of glucose to fructose (B).

According to their report [34], complex between $\mathrm{CrCl}_{2}$ and the IL interacts with the open chain glucose and helps in the isomerization to fructose and the direct conversion to 5-HMF (Figure 18). It was suggested that the mutarotation of the a-anomer to the $\beta$-anomer of glucose is the key step of the reaction

On the other hand, Binder et al. [1] proposed two variations on the mechanism previously suggested by Zhao et al (Figure 19). It was concluded that the fructofuranosyl cation undergoes attacks by chloride, bromide, or iodide. As bromide and iodide are better leaving groups than chloride, they were deemed as effective ionic additives. Chromium salts play an important role in the yield of 5-HMF. Research has shown that the yield of 5-HMF using chromium correlates with metal coordination. It was also proposed that the halide additives serve two roles: (1) as ligands for the chromium cation and (2) they facilitate the selective conversion of fructose. 

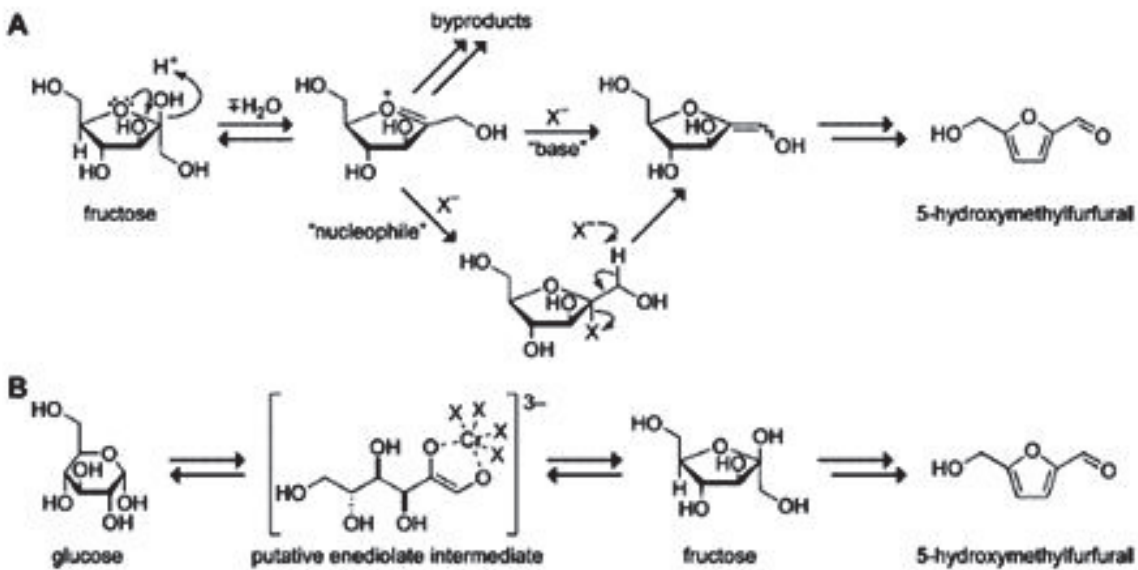

Fig. 18. Two possible mechanisms for the dehydration of fructose and isomerization of glucose.
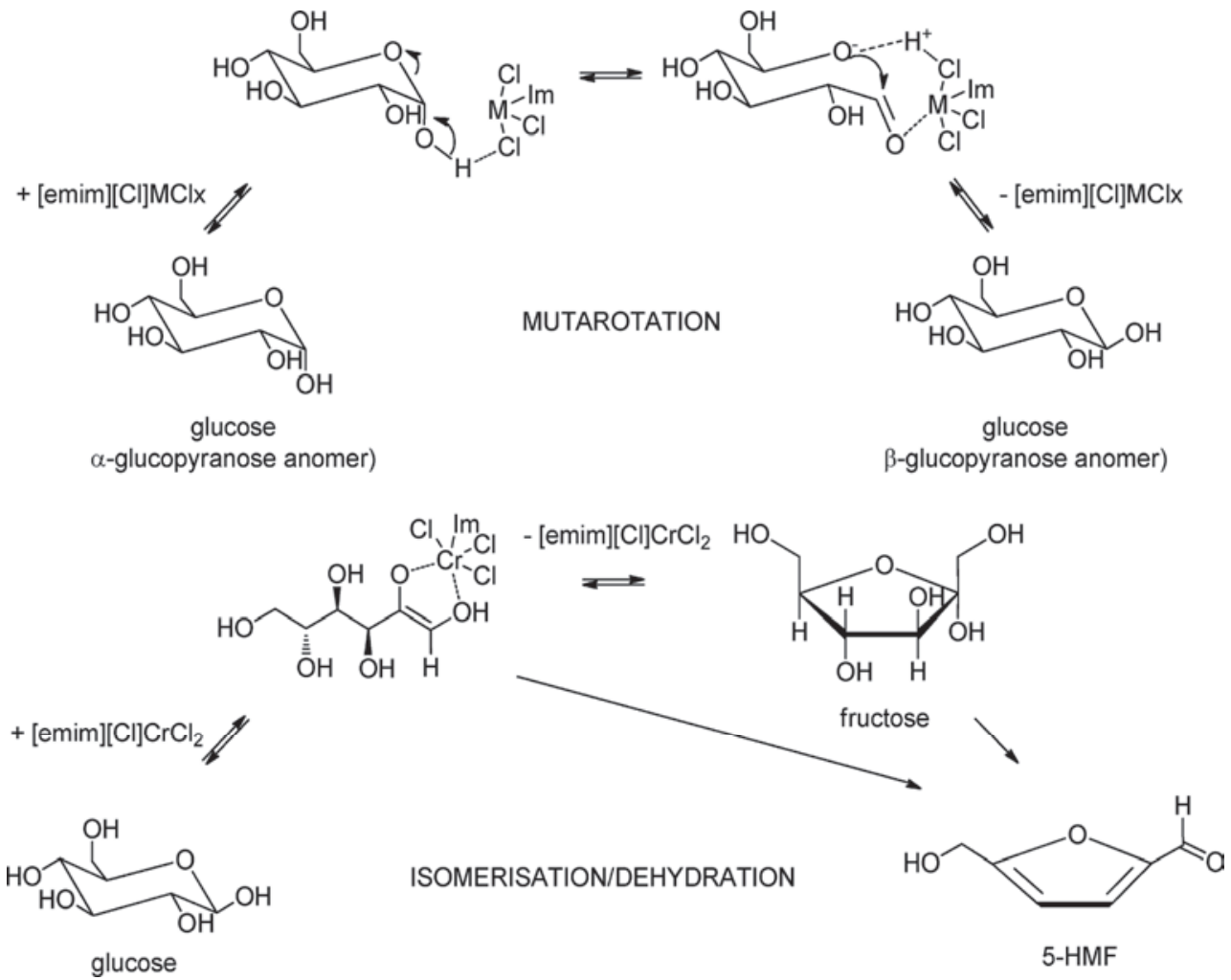

Fig. 19. Proposed metal halide interactions with glucose in [EMIM][Cl] [34]. 


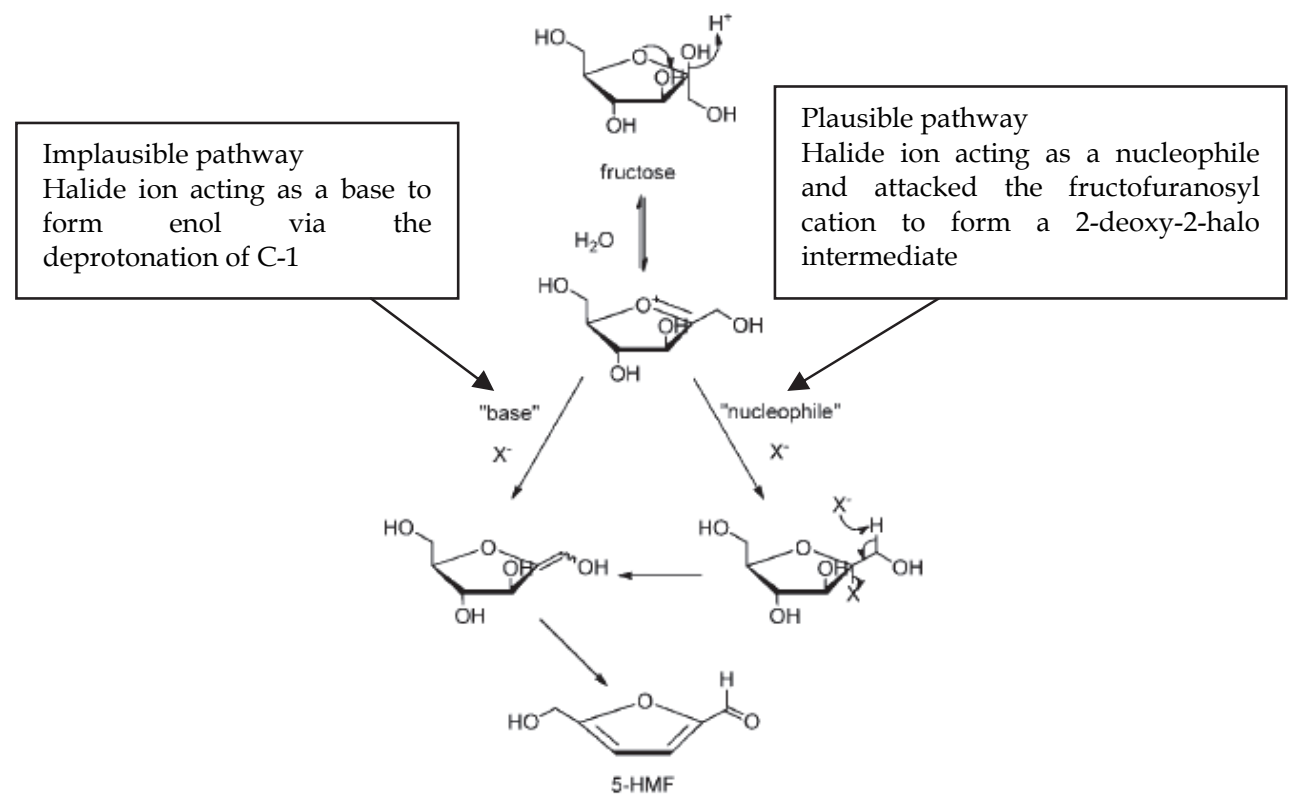

Fig. 20. Importance of halide in the mechanism (basic nucleophilic) of dehydration fructose to 5-HMF [1].

\subsection{N-heterocyclic carbenes (NHCs)}

It has been reported that there was no unusual observations in the catalytic activity for the previously described $\mathrm{CrCl}_{2} /[\mathrm{BMIM}][\mathrm{Cl}]$ catalytic system [36]. The chromium (II) chloride catalyst, modified with $N$-heterocyclic carbenes (NHCs), was investigated to show the stereochemical properties of the NHCs and not the oxidation states of the chromium that influence the catalytic properties. The best yields were achieved for the 1,3-bis(2,6diisopropylphenyl)imidazolylidiene ligand that gave $96 \%$ and $81 \%$ yields of $5-\mathrm{HMF}$ for fructose and glucose, respectively [36]. Interestingly, Zhao and coworkers used microwave irradiation and obtained the best results in ionic liquid for the conversion of glucose to 5HMF with a yield of $91 \%$ [35]. Microwave-assisted reactions have great potential as they significantly reduce the amount of time required to complete the reactions.

\subsection{Heterogeneous catalyst system}

Solid catalyst, Amberlyst-15 sulfonic ion-exchange resin, proved to be the most effective solid catalyst that gave $82 \%$ yield of $5-\mathrm{HMF}$ after 1 minute at $120^{\circ} \mathrm{C}$ [37]. Immobilization of homogeneous catalyst on solid support also demonstrated good activity. It was found that the immobilized ILs and acid modified silica gel were effective for the dehydration of fructose to 5-HMF. The advantages of using solid catalyst are in the area of product separation and catalyst recycling.

\subsection{Dehydration of oligosaccharides to 5-HMF in ILs}

Inulin, also known as fructan, is a carbohydrate that consists of fructose units with degrees of polymerization (DP) ranging from 2 to 60 . The fructosyl units are linked by $\beta(2 \rightarrow 1)$ 
linkages with the glucose as the terminating unit of the polymer chain [38]. Inulins are found in plants such as artichoke tuber and chicory root and stored as energy sources. Since inulin-type fructans are resistant to hydrolysis by digestive enzymes in human intestine, they are classified as non-digestible carbohydrates as they [39]. Qi et al reported an effective one pot [40], two-step process for the production of 5-HMF using inulin in ionic liquids under mild conditions. Combining [BMIM] [Cl] and a strong acidic cation exchange resin gave a 5-HMF yield of $55 \%$ in $20 \mathrm{~min}$. Subsequently, a two-step in one pot system was reported in which two bronsted acidic ILs, [EMIM] [HSO $\left.{ }_{4}\right]$ and [BMIM] $\left[\mathrm{HSO}_{4}\right]$, acted as both solvent and catalyst for the conversion of inulin with a $5-\mathrm{HMF}$ yield of $82 \%$ at $80^{\circ} \mathrm{C}$ in 65 min. The advantage of the mixed ionic liquid system is that it is green and efficient system because recycling of the ILs is a simple process.

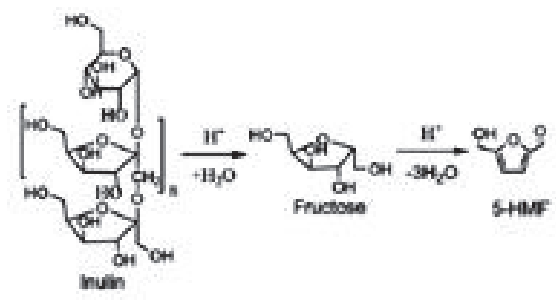

Fig. 21. The pathways for acid-catalyzed hydrolysis and dehydration of inulin to 5-HMF.

\subsection{Dehydration of polysaccharides to 5-hydroxymethylfurfural (5-HMF) in ILs}

For the synthesis of 5-HMF, N,N-dimethylacetamide (DMA) was used with lithium chloride $(\mathrm{LiCl})$ in a single step from untreated lignocellulosic biomass [1], purified cellulose, glucose and fructose, since the conversion of cellulose to 5-HMF is unaffected by the presence of other biomass such as lignin and protein (Figure 22) [1].

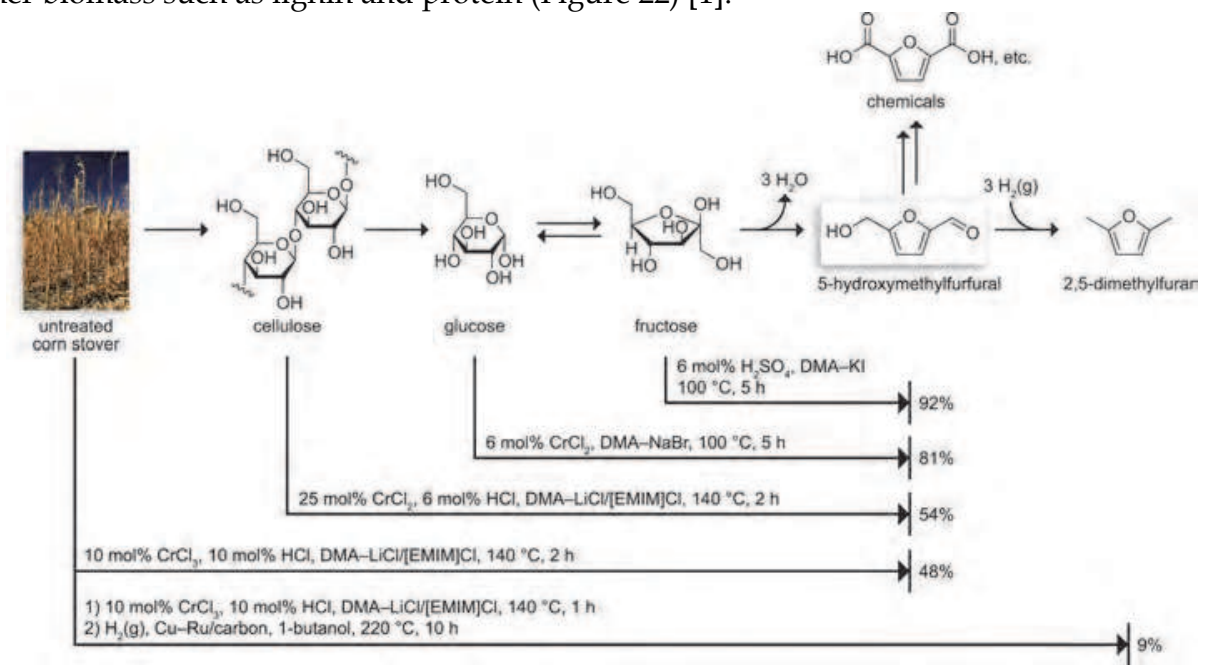

Fig. 22. Halide salts in DMA enable previously exclusive yields of bio-based chemicals from a variety of carbohydrates. 
The production of 5-HMF and furfural from lignocellulosic biomass (corn stalk, rice straw and pine wood) in ILs, catalyzed by $\mathrm{CrCl}_{3}$ under microwave irradiation, was reported with yields $45-52 \%$ and $23-31 \%$ respectively, from corn stalk, rice straw and pine wood in less than $3 \mathrm{~min}$ (Table 2) [3]. This method paved the way for energy-efficient and cost-effective conversion of biomass into biofuels and platform chemicals [3].

\begin{tabular}{|c|c|c|c|c|c|}
\hline Entry & Sample & Catalyst & $\begin{array}{l}\text { Time } \\
\text { (min) }\end{array}$ & $\begin{array}{l}\text { HMF yield } \\
(\%)\end{array}$ & $\begin{array}{l}\text { Furfural yield } \\
(\%)\end{array}$ \\
\hline 1 & Cellulose & $\mathrm{CrCl}_{3} \cdot 6 \mathrm{H}_{2} \mathrm{O}$ & 2.5 & 62 & nd \\
\hline 2 & Xylan & $\mathrm{CrCl}_{3} \cdot 6 \mathrm{H}_{2} \mathrm{O}$ & 2 & nd & 63 \\
\hline 3 & Xylan & - & 2 & nd & 18 \\
\hline 4 & Cellulose + xylan & $\mathrm{CrCl}_{3} \cdot 6 \mathrm{H}_{2} \mathrm{O}$ & 2 & 39 & 55 \\
\hline 5 & Cellulose + xylan & $\mathrm{CrCl}_{3} \cdot 6 \mathrm{H}_{2} \mathrm{O}$ & 2.5 & 53 & 33 \\
\hline 6 & Corn stalk & $\mathrm{CrCl}_{3} \cdot 6 \mathrm{H}_{2} \mathrm{O}$ & 3 & 45 & 23 \\
\hline 7 & Rice straw & $\mathrm{CrCl}_{3} \cdot 6 \mathrm{H}_{2} \mathrm{O}$ & 3 & 47 & 25 \\
\hline 8 & Pine wood & $\mathrm{CrCl}_{3} \cdot 6 \mathrm{H}_{2} \mathrm{O}$ & 3 & 52 & 31 \\
\hline $9^{\underline{b}}$ & Pine wood & $\mathrm{CrCl}_{3} \cdot 6 \mathrm{H}_{2} \mathrm{O}$ & 3 & 44 & 28 \\
\hline $10^{\mathrm{c}}$ & Pine wood & $\mathrm{HCl}$ & 60 & 2.1 & 4.4 \\
\hline $11^{-\frac{d}{d}}$ & Pine wood & $\mathrm{CrCl}_{3} \cdot 6 \mathrm{H}_{2} \mathrm{O}$ & 60 & 6.4 & 7.0 \\
\hline $12^{\mathrm{e}}$ & Pine wood & $\mathrm{CrCl}_{3} \cdot 6 \mathrm{H}_{2} \mathrm{O}$ & 6 & 35 & 18 \\
\hline
\end{tabular}

nd $=$ not detected

a Unless otherwise specified, reaction conditions were: substrate $(100 \mathrm{mg})$ and $\mathrm{CrCl}_{3} \cdot 6 \mathrm{H}_{2} \mathrm{O}(10 \mathrm{mg}$, $0.0375 \mathrm{mmol}$ ) were added to $2.0 \mathrm{~g}$ of $\left[\mathrm{C}_{4} \mathrm{mim}\right] \mathrm{Cl}$, followed by $\mathrm{MI}$ at $400 \mathrm{~W}$ for the desired time. Yields of HMF from corn stalk, rice straw and pine wood were based on a hexose content of $36.1 \%, 37.5 \%$ and $54 \%$, and yields for furfural were based on a pentose content of $21.4 \%, 21.2 \%$ and $7.6 \%$, respectively. ${ }^{\mathrm{b}}\left[\mathrm{C}_{4} \mathrm{mim}\right] \mathrm{Br}$ was used as a reaction medium. ${ }^{\mathrm{c}}$ Reaction conditions were: $20 \mathrm{mg}$ of hydrochloric acid, $2.0 \mathrm{~g}$ of $\left[\mathrm{C}_{4} \mathrm{mim}\right] \mathrm{Cl}, 30 \mathrm{mg}$ of $\mathrm{H}_{2} \mathrm{O}, 0.1 \mathrm{~g}$ of pine wood, $100{ }^{\circ} \mathrm{C}$ with an oilbath. ${ }^{\mathrm{d}}$ Reaction conditions were: $10 \mathrm{mg}$ of $\mathrm{CrCl}_{3} 6 \mathrm{H}_{2} \mathrm{O}, 2.0 \mathrm{~g}$ of $\left[\mathrm{C}_{4} \mathrm{mim}\right] \mathrm{Cl}, 0.1 \mathrm{~g}$ of pine wood, $100{ }^{\circ} \mathrm{C}$

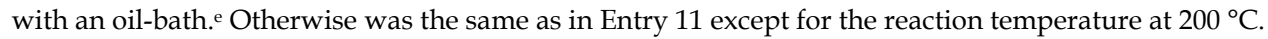

Table 2. Production of furan compounds under microwave irradiation. ${ }^{a}$

\subsection{Challenges}

In summary, one of the main challenges is picking the appropriate starting materials by considering the different aspects such as the availability, renewability, cost, viability, efficiency and so on. Currently, good and reasonable yields for the conversion of monosaccharides to 5-HMF can be achieved with the use of fructose and glucose. Since, glucose is a human food derived from starch and fructose is derived by an additional workup from the enzymatic hydrolysis of glucose, the search for alternative starting materials that are renewable and from non-food sources presents challenges that must be overcome. Another challenge would be found in up-scaling the reaction in ILs. The design and development of an efficient, simple, effective, high selectivity reactor and reaction system is necessary for the commercialization of this technology. 


\section{Transformation of oleate to value added chemicals}

\subsection{The oleochemical industry}

Ever since the crude oil crisis in the late 1970s (Figure 23) [41], manufacturers have been switching from petrochemical to the oleohemicals that lead to a global expansion of the oleochemical industry. The oleochemical industry makes chemicals from renewable resources such as natural oils and fats in addition to waste or by-products from the food industry. Natural oils and fats are primarily composed of long chains of triglycerides with carboxylic acids. The primary olechemical products consist of glycerols, fatty acids, fatty alcohols and fatty acid methyl esters (FAME). These chemicals are useful raw materials for lubricants, fuels (biodiesels), paints, polymers (polyester), surfactants, detergents, soaps and cosmetics. Oleates are a class of fatty acid esters that are commonly synthesized from the reaction of natural fats and oils with methanol, catalyzed by alkali.

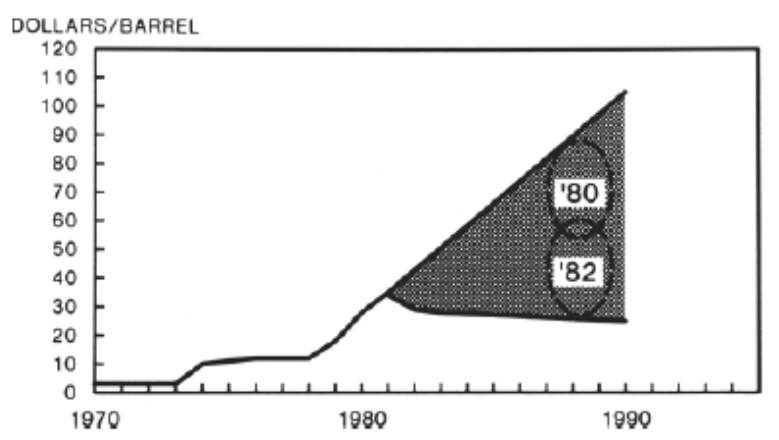

Fig. 23. Crude oil price projections, 1980 vs 1982. US refinery average acquisition costs, current dollars [41].

\subsection{Transformation of oleates using olefin metathesis}

After the first report on the $\mathrm{WCl}_{6} / \mathrm{SnMe}_{4}$ catalytic system for the metathesis of methyl oleate in 1972 [42], olefin metathesis has been considered as a useful catalytic reaction. It converts olefins into new and useful products by breaking and reforming the $\mathrm{C}=\mathrm{C}$ bonds. The key step involves the formation of the [2+2] metallacyclobutane intermediate of the olefin and the transition metal alkylidene complex [43].

\subsubsection{Homo-metathesis reaction of methyl oleate}

In 1972, Boelhouwer and co-workers reported the selective transformation of methyl oleate to equimolar amounts of 9-octadecene and dimethyl 9-octadecene-1,18-dioate using $\mathrm{WCl}_{6} /\left(\mathrm{CH}_{3}\right)_{4} \mathrm{Sn}$ as the catalyst (Figure 24) [42].

The successful metathesis of methyl oleate has led to the synthesis of many other unsaturated fatty acid esters with high selectivity. The development of homogeneous and heterogeneous catalyst systems and the metathesis of $\omega$-unsaturated fatty acid esters such as methyl 10-undecenoate, that proceeds to completion via the continuous removal of the volatile co-product, ethylene, is an example of an industrial process based on these reactions (Figure 25). 


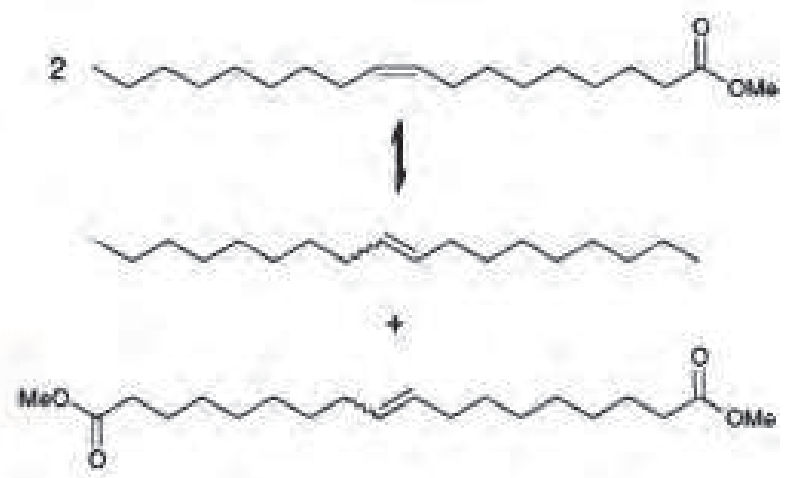

Fig. 24. Homo-metathesis of methyl oleate [42].

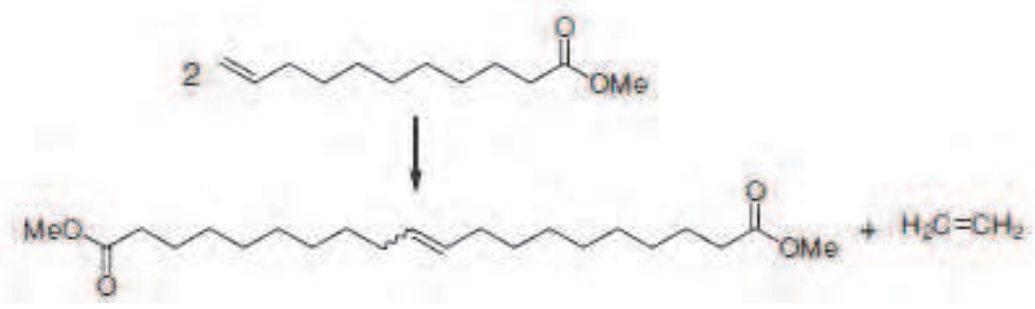

Fig. 25. Homo-metathesis reaction of methyl oleate.

\subsubsection{Cross-metathesis reaction of unsaturated fatty acid esters}

Cross-metathesis allows long chain unsaturated fatty acid esters to be shorten to produce highly desirable short chain esters such as detergent-range $C_{10}-C_{14}$ esters (methyl 9dodecenoate); the alkene co-products can be converted to $\mathrm{C}_{12}-\mathrm{C}_{14}$ alcohols by hydroformylation. The cross-metathesis of unsaturated fatty acids with ethylene (Figure 26), or ethenolysis produce highly valuable short chain $\omega$-unsaturated fatty acid esters. Various groups have reported on the ethenolysis of methyl oleate to form methyl 9-decenoate and 1decene. Both methyl 9-decenoate and 1-decene are the key intermediates for the synthesis of chemical products (fragrances, lubricants [44]) and polymers (polyesters, polyamides), respectively.

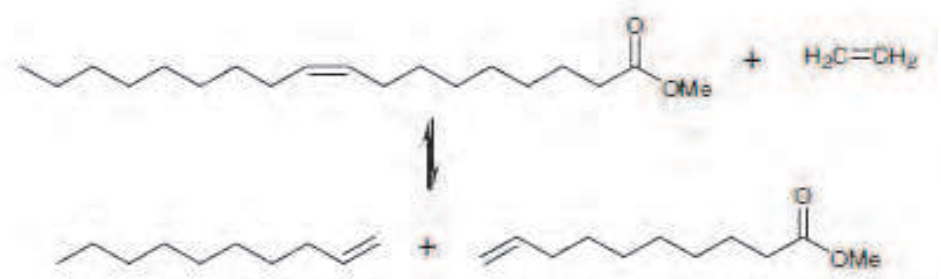

Fig. 26. Cross-metathesis of methyl oleate 


\subsubsection{Ethenolysis of methyl oleate in lonic liquid [45]}

In 2007, Bourbigou-Dixneuf and coworkers took the ethenolysis procedure one step further and reported the ethenolysis of methyl oleate using ionic liquids. They screened two imidazolium based ionic liquids of different counter anions and found that Hoveyda catalyst 8 (Figure 27) and [bdmim] $\left[\mathrm{NTf}_{2}\right]$ ionic liquid gave the best conversion (95\%) and high catalyst recyclability of 3 consecutive runs without significant loss in catalytic activity [45].

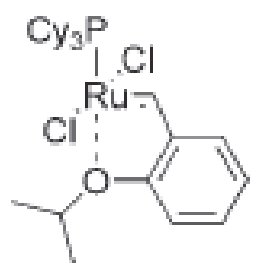

8

Fig. 27. Hoveyda catalyst.

\subsection{Conclusions}

The demand for inexpensive and renewable energy and chemical products will further spur the oleochemical industry. The metathesis of oleates offers new synthetic routes to valuable raw materials and feed stocks with high chemoselectivity. The reaction is catalytic and could be performed at ambient conditions. Moreover, solvents could be substituted with "green" ionic liquids that will further enhance the growth of production.

\section{Conclusions and perspectives}

Because of their high availability and low prices, the chemical industries in thelatter part of $20^{\text {th }}$ and the early $21^{\text {st }}$ century rely heavily on crude oil. However, this strong focus of raw materials now appears to be more precarious due to escalating international financial problems and unknown political factors.

At present, moving away from fossil fuel processes should be the main goal of industrial chemical development. This could be attained through the application of new technologies that utilized lignocellulosic biomass. Recent developments in ionic liquids show great potential in the utilization of lignocellulosic biomass processes; they have shown high efficacy and efficiency. One of the greatest shortcomings of ILs is their high cost; more research must be done to make them more cost-effective.

In spite of the possibilities that are opened up by using ionic liquids in biomass chemistry, both their recovery and reuse for continuous processes remain a formidable challenge for the industrialization of new technologies. Ionic liquids are relatively expensive compared to traditional solvents and the high cost of utilizing ionic liquids must be offset; this is mandatory for the development of commercially viable processes. In addition, the technology available now shows that ionic liquids can only dissolve about 10-15 wt \% cellulose to give very thick and viscous solutions at these low concentrations.

The future of $R \& D$ for biomass processing utilizing ionic liquids relies on the development of novel, environmentally-friendly ionic liquids that allow high concentrations of dissolved 
cellulose and still possess good rheological properties. Furthermore, products should be readily isolated from ionic liquids for the efficient solvent recycling. Moreover, the separation of impurities from biomass has to be efficient otherwise the accumulation of impurities during the process may negatively affect the overall performance of the system.

\section{Acknowledgements}

This work was supported by the Institute of Chemical and Engineering Sciences (ICES), Singapore. NSH thanks the grants from the National Science Foundation (CHE-0906179), NIU Inaugural Board of Trustees Professorship, and the Research Prize for Senior US Scientists from the Alexander von Humboldt Foundation. JAM gratefully acknowledges the support from the Robert A. Welch Foundation (N-1322).

\section{References}

[1] Binder, J. B.; Raines, R. T., Simple Chemical Transformation of Lignocellulosic Biomass into Furans for Fuels and Chemicals. J. Am. Chem. Soc., 2009, 131 (5), 1979-1985.

[2] Zakrzewska, M. E.; Ewa Bogel-Łukasik, E.; Bogel-Łukasik, R., Ionic Liquid-Mediated Formation of 5-Hydroxymethylfurfural - A Promising Biomass-Derived Building Block. Chem. Rev., 2011, 111(2), 397-417.

[3] Zhang, Z.; Zhao, Z. K., Microwave-assisted conversion of lignocellulosic biomass into furans in ionic liquid. Bioresource Tech., 2010, 101 (3), 1111-1114.

[4]Olivier-Bourbigou, H.; Magna, L.; Morvan, D., Ionic liquids and catalysis: Recent progress from knowledge to applications. Appl. Catal. A: General 2010, 373 (1-2), 1-56.

[5] Smiglak, M.; Holbrey, J. D.; Griffin, S. T.; Reichert, W. M.; Swatloski, R. P.; Katritzky, A. R.; Yang, H.; Zhang, D.; Kirichenko, K.; Rogers, R. D., Ionic liquids via reaction of the zwitterionic 1,3-dimethylimidazolium-2-carboxylate with protic acids. Overcoming synthetic limitations and establishing new halide free protocols for the formation of ILs. Green Chem., 2007, 9 (1), 90-98.

[6] Oxley, J. D.; Prozorov, T.; Suslick, K. S., Sonochemistry and Sonoluminescence of RoomTemperature Ionic Liquids. J. Am. Chem. Soc., 2003, 125 (37), 11138-11139.

[7] Horikoshi, S.; Hamamura, T.; Kajitani, M.; Yoshizawa-Fujita, M.; Serpone, N., Green Chemistry with a Novel 5.8-GHz Microwave Apparatus. Prompt One-Pot SolventFree Synthesis of a Major Ionic Liquid: The 1-Butyl-3-methylimidazolium Tetrafluoroborate System. Org. Proc. Res. Develop., 2008, 12 (6), 1089-1093.

[8] Himmler, S.; Konig, A.; Wasserscheid, P., Synthesis of [EMIM]OH via bipolar membrane electrodialysis - precursor production for the combinatorial synthesis of [EMIM]based ionic liquids. Green Chem., 2007, 9 (9), 935-942.

[9] Ohno, H., Functional Design of Ionic Liquids. Bull. Chem. Soc. Japan 2006, 79 (11), 16651680 .

[10] Heinze, T.; Liebert, T., Unconventional methods in cellulose functionalization. Progress in Poly. Sci., 2001, 26 (9), 1689-1762.

[11] Lee, S. H.; Doherty, T. V.; Linhardt, R. J.; Dordick, J. S., Ionic liquid-mediated selective extraction of lignin from wood leading to enhanced enzymatic cellulose hydrolysis. Biotechnology and Bioengineering 2009, 102 (5), 1368-1376.

[12] Dadi, A. P.; Varanasi, S.; Schall, C. A., Enhancement of cellulose saccharification kinetics using an ionic liquid pretreatment step. Biotechnology and Bioengineering 2006, 95 (5), 904-910. 
[13] Dadi, A.; Schall, C.; Varanasi, S., Mitigation of cellulose recalcitrance to enzymatic hydrolysis by ionic liquid pretreatment. Applied Biochemistry and Biotechnology 2007, $137-140$ (1), 407-421.

[14] Liu, L.; Chen, H., Enzymatic hydrolysis of cellulose materials treated with ionic liquid [BMIM] Cl. Chinese Science Bulletin 2006, 51 (20), 2432-2436.

[15] Mosier, N.; Wyman, C.; Dale, B.; Elander, R.; Lee, Y. Y.; Holtzapple, M.; Ladisch, M., Features of promising technologies for pretreatment of lignocellulosic biomass. Bioresource Technology 2005, 96 (6), 673-686.

[16] Grous, W. R.; Converse, A. O.; Grethlein, H. E., Effect of steam explosion pretreatment on pore size and enzymatic hydrolysis of poplar. Enzyme and Microbial Technology 1986, 8 (5), 274-280.

[17] Mes-Hartree, M.; Dale, B. E.; Craig, W. K., Comparison of steam and ammonia pretreatment for enzymatic hydrolysis of cellulose. Applied Microbiology and Biotechnology 1988, 29 (5), 462-468.

[18] Chum, H. L.; Johnson, D. K.; Black, S.; Baker, J.; Grohmann, K.; Sarkanen, K. V.; Wallace, K.; Schroeder, H. A., Organosolv pretreatment for enzymatic hydrolysis of poplars: I. Enzyme hydrolysis of cellulosic residues. Biotechnology and Bioengineering 1988, 31 (7), 643-649.

[19] Zhang, Y.-H. P.; Ding, S.-Y.; Mielenz, J. R.; Cui, J.-B.; Elander, R. T.; Laser, M.; Himmel, M. E.; McMillan, J. R.; Lynd, L. R., Fractionating recalcitrant lignocellulose at modest reaction conditions. Biotechnology and Bioengineering 2007, 97 (2), 214-223.

[20] Gierer, J.; NorÃ@@n, I., Oxidative Pretreatment of Pine Wood to Facilitate Delignification during Kraft Pulping. Holzforschung 1982, 36 (3), 123-130.

[21] Hatakka, A. I., Pretreatment of wheat straw by white-rot fungi for enzymic saccharification of cellulose. Applied Microbiology and Biotechnology 1983, 18 (6), 350357.

[22] Pu, Y.; Jiang, N.; Ragauskas, A. J., Ionic Liquid as a Green Solvent for Lignin. Journal of Wood Chemistry and Technology 2007, 27 (1), 23-33.

[23] Tan, S. S. Y.; MacFarlane, D. R.; Upfal, J.; Edye, L. A.; Doherty, W. O. S.; Patti, A. F.; Pringle, J. M.; Scott, J. L., Extraction of lignin from lignocellulose at atmospheric pressure using alkylbenzenesulfonate ionic liquid. Green Chemistry 2009, 11 (3), 339345.

[24] Zhu, L.; O'Dwyer, J. P.; Chang, V. S.; Granda, C. B.; Holtzapple, M. T., Structural features affecting biomass enzymatic digestibility. Bioresource Technology 2008, 99 (9), 3817-3828.

[25] Zavrel, M.; Bross, D.; Funke, M.; Büchs, J.; Spiess, A. C., High-throughput screening for ionic liquids dissolving (ligno-)cellulose. Bioresource Technology 2009, 100 (9), 25802587.

[26] Rayne, S. a. M., Giuseppe., Trichoderma reesei derived cellulase activity in three N,Ndimethylethanolammonium akylcarboxylate ionic liquids. Available from Nature Precedings <http://hdl.handle.net/10101/npre.2007.632.1> (2007).

[27] Zhu, Y.; Kong, Z. N.; Stubbs, L. P.; Lin, H.; Shen, S.; Anslyn, E. V.; Maguire, J. A., Conversion of Cellulose to Hexitols Catalyzed by Ionic Liquid-Stabilized Ruthenium Nanoparticles and a Reversible Binding Agent. ChemSusChem 2010, 3 (1), 67-70.

[28] Roman-Leshkov, Y.; Barrett, C. J.; Liu, Z. Y.; Dumesic, J. A., Production of dimethylfuran for liquid fuels from biomass-derived carbohydrates. Nature 2007, 447 (7147), 982-985. 
[29] Antal, M. J.; Mok, W. S. L.; Richards, G. N., Mechanism of formation of 5(hydroxymethyl)-2-furaldehyde from -fructose and sucrose. Carbohydrate Research 1990, 199 (1), 91-109.

[30] Fayet, C.; Gelas, J., Nouvelle méthode de préparation du 5-hydroxyméthyl-2furaldéhyde par action de sels d'ammonium ou d'immonium sur les mono-, oligoet poly-saccharides. Accès direct aux 5-halogénométhyl-2-furaldéhydes. Carbohydrate Research 1983, 122 (1), 59-68.

[31] Lansalot-Matras, C.; Moreau, C., Dehydration of fructose into 5-hydroxymethylfurfural in the presence of ionic liquids. Catalysis Communications 2003, 4 (10), 517-520.

[32] Qi, X.; Watanabe, M.; Aida, T. M.; Smith, R. L., Efficient Catalytic Conversion of Fructose into 5-Hydroxymethylfurfural in Ionic Liquids at Room Temperature. ChemSusChem 2009, 2 (10), 944-946.

[33] Chan, J. Y. G.; Zhang, Y., Selective Conversion of Fructose to 5-Hydroxymethylfurfural Catalyzed by Tungsten Salts at Low Temperatures. ChemSusChem 2009, 2 (8), 731734.

[34] Zhao, H.; Holladay, J. E.; Brown, H.; Zhang, Z. C., Metal Chlorides in Ionic Liquid Solvents Convert Sugars to 5-Hydroxymethylfurfural. Science 2007, 316 (5831), 1597-1600.

[35] Li, C.; Zhang, Z.; Zhao, Z. K., Direct conversion of glucose and cellulose to 5hydroxymethylfurfural in ionic liquid under microwave irradiation. Tetrahedron Letters 2009, 50 (38), 5403-5405.

[36] Yong, G.; Zhang, Y.; Ying, J. Y., Efficient Catalytic System for the Selective Production of 5-Hydroxymethylfurfural from Glucose and Fructose. Angewandte Chemie International Edition 2008, 47 (48), 9345-9348.

[37] Hu, S.; Zhang, Z.; Zhou, Y.; Han, B.; Fan, H.; Li, W.; Song, J.; Xie, Y., Conversion of fructose to 5-hydroxymethylfurfural using ionic liquids prepared from renewable materials. Green Chemistry 2008, 10 (12), 1280-1283.

[38] Sirisansaneeyakul, S.; Worawuthiyanan, N.; Vanichsriratana, W.; Srinophakun, P.; Chisti, Y., Production of fructose from inulin using mixed inulinases from \&lt;i\&gt;Aspergillus niger\&lt;/i\&gt; and \&lt;i\&gt;Candida guilliermondii\&lt;/i\&gt. World Journal of Microbiology and Biotechnology 2007, 23 (4), 543-552.

[39] Verghese, M.; Walker, L. T.; Shackelford, L.; Chawan, C. B., Inhibitory effects of nondigestible carbohydrates of different chain lengths on azoxymethane-induced aberrant crypt foci in Fisher 344 rats. Nutrition Research 2005, 25 (9), 859-868.

[40] Qi, X.; Watanabe, M.; Aida, T. M.; Smith Jr, R. L., Efficient one-pot production of 5hydroxymethylfurfural from inulin in ionic liquids. Green Chemistry 12 (10), 18551860.

[41] Haupt, D.; Drinkard, G.; Pierce, H., Future of petrochemical raw materials in oleochemical markets. Journal of the American Oil Chemists' Society 1984, 61 (2), 276-281.

[42] van Dam, P. B.; Mittelmeijer, M. C.; Boelhouwer, C., Metathesis of unsaturated fatty acid esters by a homogeneous tungsten hexachloride-tetramethyltin catalyst. Journal of the Chemical Society, Chemical Communications 1972, (22), 1221-1222.

[43] Mol, J. C., Catalytic Metathesis of Unsaturated Fatty Acid Esters and Oils. Topics in Catalysis 2004, 27 (1), 97-104.

[44] Yadav, G. D.; Doshi, N. S., Development of a green process for poly-[small alpha]-olefin based lubricants. Green Chemistry 2002, 4 (6), 528-540.

[45] Thurier, C.; Fischmeister, C.; Bruneau, C.; Olivier-Bourbigou, H.; Dixneuf, P. H., Ethenolysis of Methyl Oleate in Room-Temperature Ionic Liquids. ChemSusChem 2008, 1 (1-2), 118-122. 
APPUications of

IONIC LIQUIDS IN SCIENCE

AND TECHNOLOGY

Edand by Scott Handy

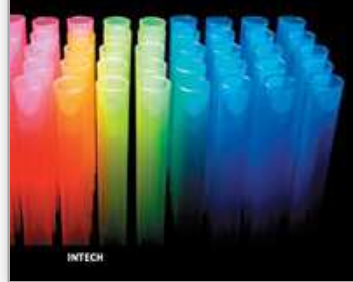

\section{Applications of lonic Liquids in Science and Technology}

Edited by Prof. Scott Handy

ISBN 978-953-307-605-8

Hard cover, 516 pages

Publisher InTech

Published online 22, September, 2011

Published in print edition September, 2011

This volume, of a two volume set on ionic liquids, focuses on the applications of ionic liquids in a growing range of areas. Throughout the 1990s, it seemed that most of the attention in the area of ionic liquids applications was directed toward their use as solvents for organic and transition-metal-catalyzed reactions. Certainly, this interest continues on to the present date, but the most innovative uses of ionic liquids span a much more diverse field than just synthesis. Some of the main topics of coverage include the application of RTILs in various electronic applications (batteries, capacitors, and light-emitting materials), polymers (synthesis and functionalization), nanomaterials (synthesis and stabilization), and separations. More unusual applications can be noted in the fields of biomass utilization, spectroscopy, optics, lubricants, fuels, and refrigerants. It is hoped that the diversity of this volume will serve as an inspiration for even further advances in the use of RTILs.

\section{How to reference}

In order to correctly reference this scholarly work, feel free to copy and paste the following:

Zhu Yinghuai, Algin Oh Biying, Xiao Siwei, Narayan S Hosmane and John A. Maguire (2011). Ionic Liquids in Catalytic Biomass Transformation, Applications of Ionic Liquids in Science and Technology, Prof. Scott Handy (Ed.), ISBN: 978-953-307-605-8, InTech, Available from: http://www.intechopen.com/books/applications-ofionic-liquids-in-science-and-technology/ionic-liquids-in-catalytic-biomass-transformation

\section{INTECH}

open science | open minds

\author{
InTech Europe \\ University Campus STeP Ri \\ Slavka Krautzeka 83/A \\ 51000 Rijeka, Croatia \\ Phone: +385 (51) 770447 \\ Fax: +385 (51) 686166 \\ www.intechopen.com
}

\author{
InTech China \\ Unit 405, Office Block, Hotel Equatorial Shanghai \\ No.65, Yan An Road (West), Shanghai, 200040, China \\ 中国上海市延安西路65号上海国际贵都大饭店办公楼405单元 \\ Phone: +86-21-62489820 \\ Fax: $+86-21-62489821$
}


(C) 2011 The Author(s). Licensee IntechOpen. This chapter is distributed under the terms of the Creative Commons Attribution-NonCommercialShareAlike-3.0 License, which permits use, distribution and reproduction for non-commercial purposes, provided the original is properly cited and derivative works building on this content are distributed under the same license. 